\title{
The Implementation of Information Literacy in Learning Islamic Religious Education
}

\author{
Suci Nurpratiwi \\ \{sucinurpratiwi@unj.ac.id\} \\ Faculty of Social Science, State University Jakarta, Indonesia
}

\begin{abstract}
This study aimed to describe and analyze the implementation of information literacy in learning Islamic Religious Education at Al-Izhar Islamic High School. Information literacy is closely related to the ability to think critically. This study applied a qualitative approach, with a type of case study research. The results indicate that the implementation of information literacy in learning Islamic Religious Education at AlIzhar Islamic High School is very good, as seen from the role of PAI teachers who was so great in the process of developing information literacy in classroom learning, encourage habituation activities to students, and support the additional lessons.
\end{abstract}

Keywords: Information Literacy, Learning, Teacher, Critical Thinking Skill.

\section{Introduction}

Facing the 21st century, fierce competition in welcoming the era of the industrial revolution 4.0 requires that everyone has the ability and expertise that is qualified digitally based. Globalization and modernization that occur quickly, have an impact on the swift challenges that need to be faced, in order to be able to prepare superior human resources.

The 21st Century formula states that in order to survive and adapt to transform in a global scope, special skills are needed, namely communication, collaboration, critical thinking, and creative. So educational institutions need to prepare humans with advanced human resources to be competitive in facing global competition. Quality human resources will be the main driver of development in various sectors of life.

In the era of the industrial revolution 4.0 as it is today, many people believe that the civilization of the future is the civilization of the information society with the understanding that information has become the main thing, and interaction between humans is based on information and communication technology. Sailah explained that there are new approaches to literacy, namely digital literacy, technological literacy, and human literacy [1]. The most important aspect of the three is information. With the development of technology, currently information can be obtained and published easily. But on the other hand, this convenience can also make people experience confusion in choosing which information can be trusted, or who is a source worth quoting. So that it can raise concerns about the use of information itself.

Information literacy is part of a person's information needs. Someone who is literate will be able to search, choose, analyze, and can efficiently use the information obtained to deal with any existing problems.

Thompson explained, information literacy is knowing how to learn. It is knowing how to find information, evaluate it, and use it wisely and effectively. Information literacy skills include recognzing when information is needed, selecting appropriate sources from the overwhelming amount of available print and nonprint resources, evaluating the information 
for accuracy and pertinence, organizing the facts so that they make sense, creating knowledge by associating the new information with previous knowledge and experiences, and then using this knowledge wisely [2].

Education must be able to empower all people to change information into new knowledge and useful in their lives. Schools are the main point in shaping the creation of information literacy.

The challenge that then arises is how schools can anticipate the massive impact of digitalbased information dissemination, especially information related to religious aspects. The unlimited use of the internet allows students at school to access religious information anywhere and anytime, including information that cannot be justified. This is very worrying if coupled with the lack of faith and fragility of the critical power of students in understanding the information, which leads to the imitation and blind fanatics in studying religion.

Several studies have shown, as quoted by VOA Indonesia, the Indonesian Intelligence Agency (BIN) stated that at this time young Indonesians are beginning to be exposed to radicalism. So they have extreme understandings of religion, with the most obvious indicator being increasing values of intolerance [3]. The Wahid Foundation -which operates in the field of democracy - said that almost $60 \%$ of participants in Islamic religious activities (Rohis) in educational institutions were "ready to jihad by violence" [4]. The low literacy of information about religion can be a serious threat because it can affect one's credibility in his life and work which directly causes social and religious problems in society.

Information literacy requires the ability to analyze information to be used appropriately to solve problems. To be literate about religious information, students must have the critical power of the information they get. However, the ability to think critically cannot just develop, but must be accustomed. Critical thinking is the main indicator of supporting information literacy.

Educational institutions need to try to develop students' critical attitudes. So students do not fall into radical and misguided understandings. At school, critical thinking skills can be developed through the learning process that teachers do in the classroom. The teacher needs to hone the critical power of students so that students are literate to the information around them.

The American Association of School Librarians and the Association for educational Communications and Technology established an information literacy competency standard for the school level, namely Information Literacy Standards for Student Learning: Standards and Indicators. This information literacy standard provides a concept to describe students who master information literacy. This standard consists of 3 categories, 9 standards, and 29 indicators. These standards and indicators describe the content and process of information that students must master to be able to enter the category of people who are literating information. $[5]$.

\section{Methodology}

This research was conducted at Al-Izhar Islamic High School Pondok Labu, Jl RS Fatmawati Kav No.49, Cilandak, Kota Jakarta Selatan, Daerah Khusus Ibukota Jakarta 12450. The method used is a qualitative research approach, with a type of case study research. Data collection was carried out by observation, interview, and documentation techniques.

Primary data sourced from direct informants who were met in the field by conducting interviews and observations. While secondary data are literature, books and supporting documents. 
Interviews were conducted with the deputy of headmaster; two PAI teachers in SMA AlIzhar, namely Mr. Meta and Mr. Chairiman; class X and XI students, library student (Sipus), namely Syahla; and the school librarian. The interview was conducted in a structured and unstructured technique.

Observation was held by paying attention and directly wittness to the learning activities that occur in the classroom, outside the classroom, and in the library. Observation methods are used to observe how teacher apply information literacy strategies to students, how much learning activities are able to encourage the growth of information literacy skills of students in the classroom, and how the role of school academic community in seeking the growth of students' information literacy abilities.

The researcher also collected some documents such as lesson plans (Rencana Pelaksanaan Pembelajaran), students scientific work, and library programs.

The data analysis technique used in this study is qualitative analysis. The steps of the research carried out are 1) the orientation stage, this stage is a preliminary step, which is to detect and know the situation or condition of the research location so that the research to be carried out is as planned; 2) exploration stage, the implementation of what has been planned; 3) data checking, i.e. the author checks the data that has been collected; 4) triangulation stage, compare the results of observations, documentation and interview results, so that conclusions are obtained for research reports.

\subsection{Instruments}

Table 1. AASL Information Literacy Standards

Category L1: Information Literacy/The student who is information literate:

Standard L1-1: Access information efficiently and effectively, as described by the following indicators:

1. recognizes the need for information;

2. recognizes that accurate and comprehensive information is the basis for intelligent decision making;

3. formulates questions based on information needs;

4. identifies a variety of potential sources of information;

5. develops and uses successful strategies for locating information.

Standard L1-2: Evaluates information critically and competently, as described by the

following indicators:

1. determines accuracy, relevance, and comprehensiveness;

2. distinguishes among fact, point of view, and opinion;

3. identifies inaccurate and misleading information;

4. selects information appropriate to the problem or question at hand.

Standard L1-3: Uses information effectively and creatively, as described by the following indicators:

1. organizes information for practical application;

2. integrates new information into one's own knowledge;

3. applies information in critical thinking and problem solving;

4. produces and communicates information and ideas in appropriate formats.

Category L2: Independent Learning/The student who is an independent learner is information 


\begin{tabular}{|c|}
\hline $\begin{array}{l}\text { literate and: } \\
\text { Standard L2-1: Pursues information related to personal interests, as described by the following } \\
\text { indicators: }\end{array}$ \\
\hline $\begin{array}{l}\text { 1. seeks information related to various dimensions of personal well-being, such a career } \\
\text { interests, community involvement, health matters, and recreational pursuits; }\end{array}$ \\
\hline $\begin{array}{l}\text { 2. designs, develops, and evaluates information products and solutions related to personal } \\
\text { interests. }\end{array}$ \\
\hline $\begin{array}{l}\text { Standard L2-2: Appreciates literature and other creative expressions of information, as } \\
\text { described by the following indicators: }\end{array}$ \\
\hline 1. is a competent and self-motivated reader; \\
\hline 2. derives meaning from information presented creatively in a variety of formats; \\
\hline 3. develops creative products in a variety of formats. \\
\hline $\begin{array}{l}\text { Standard L2-3: Strives for excellence in information seeking and knowledge generation, as } \\
\text { described by the following indicators: }\end{array}$ \\
\hline 1. assesses the quality of the process and products of personal information seeking; \\
\hline 2. devises strategies for revising, improving, and updating self-generated knowledge. \\
\hline $\begin{array}{l}\text { Category L3: Social Responsibility/The student who contributes positively to the learning } \\
\text { community and to society is information literate and: }\end{array}$ \\
\hline $\begin{array}{l}\text { Standard L3-1: Recognizes the importance of information to a democratic society, as } \\
\text { described by the following indicators: }\end{array}$ \\
\hline 1. seeks information from diverse sources, contexts, disciplines, and cultures; \\
\hline 2. respects the principle of equitable access to information. \\
\hline $\begin{array}{l}\text { Standard L3-2: Practices ethical behavior in regard to information and information } \\
\text { technology, as described by the following indicators: }\end{array}$ \\
\hline 1. respects the principles of intellectual freedom; \\
\hline 2. respects intellectual property rights; \\
\hline 3. uses information technology responsibly. \\
\hline $\begin{array}{l}\text { Standard L3-3: Participates effectively in groups to pursue and generate information, as } \\
\text { described by the following indicators: }\end{array}$ \\
\hline 1. shares knowledge and information with others; \\
\hline 2. respects others' ideas and backgrounds and acknowledges their contributions; \\
\hline $\begin{array}{l}\text { 3. collaborates with others, both in person and through technologies, to identify information } \\
\text { problems and to seek their solutions; }\end{array}$ \\
\hline $\begin{array}{l}\text { 4. collaborates with others, both in person and through technologies, to design, develop, and } \\
\text { evaluate information products and solutions. }\end{array}$ \\
\hline
\end{tabular}

Table 2. Instruments interview for PAI teachers

\begin{tabular}{|l|l|}
\hline \multicolumn{1}{|c|}{ Variable } & \multicolumn{1}{|c|}{ Indicator } \\
\hline Information & $-\begin{array}{l}\text { Activities and activeness of students in } \\
\text { Literacy in classroom }\end{array}$ \\
Islamic & $-\begin{array}{l}\text { Methods for developing students' critical } \\
\text { Education }\end{array}$ \\
\hline
\end{tabular}




\begin{tabular}{|l|l|}
\hline - The role of teacher in the learning process \\
- Collaborative activities with the library \\
- Giving assignments to students \\
- Use of print or non-print resources in \\
learning \\
- Scientific work subjects \\
- Students activities outside the classroom \\
- Student religious activities \\
- Students religious knowledge and \\
- understanding
\end{tabular}

Table 3. Instrumen interview for students

\begin{tabular}{|l|l|}
\hline \multicolumn{1}{|c|}{ Variable } & \multicolumn{2}{|c|}{ Indicators } \\
\hline Information & - Teacher teaching methods of teachers in \\
Literacy in & the classroom \\
Islamic & - Assignments from teachers \\
Education & - The role of teacher in helping to find the \\
& information that students needed \\
& - The use of libraries in accessing \\
& information sources \\
& - Student religious activities \\
& - Students religious knowledge and \\
& understanding \\
& - Students' religious practice \\
\hline
\end{tabular}

Table 4. Instrument interview for librarians

\begin{tabular}{|l|l|}
\hline \multicolumn{1}{|c|}{ Variable } & \multicolumn{1}{|c|}{ Indicators } \\
\hline Information & - Student activities in the library \\
Literacy in & - Resources used by students in accessing \\
Islamic & information \\
Education & - Library collection \\
& $\begin{array}{l}\text { - Library efforts to improve student } \\
\text { information literacy } \\
\end{array}$ \\
& - Library programs \\
& - Student visits to the library \\
\hline
\end{tabular}

\section{Results}

The role of PAI teachers was so great in the process of developing information literacy. Learning at Al-Izhar Islamic High School emphasizes critical thinking skills, by doing every subject teacher. Every teacher is required to use the Inquiry Based Learning (IBL) and Evidence Based Practice (EBP) learning approaches in delivering subject matter. Inquirybased learning is learning that emphasizes the ability of students to be able to process critical power in learning each subject, in addition to evidence-based learning strengthens the readiness of students to carry out learning.

The implementation of information literacy in PAI learning is as follows: 


\section{A. Implementation in learning}

1. Teachers apply various learning methods that develop students' critical thinking skills

In delivering material, teachers often use different methods for each class or each level (grade). Because every material is different, so the target achievement is different, then the method the teacher uses adjusts to the material to be conveyed. This is as stated in the Learning Implementation Plan that was prepared by the teacher at the beginning of the school year. The method that the teacher usually uses in class is the method of discussion, presentation, question and answer, and meaning.

The discussion method is one way of presenting lessons by exposing students to a problem that can be in the form of problematic questions to be discussed and solved together. This method is carried out in order to stimulate students' creativity, accustom students to exchange ideas, train students to be skilled in expressing opinions, broaden their horizons, and produce stronger answers and solutions.

Discussing the material of the next chapter, teacher uses the question and answer method. This method can be used to attract students' attention, stimulate thinking power, build courage, practice speaking skills, and think regularly, as well as a tool to determine the level of student ability objectively.

Discussing the next chapter, the method that teacher uses is the presentation method. This is as an effort to build self-confidence, courage, and responsible attitudes of students. In addition to being able to make students explore their knowledge so that they can present and inform it well to their peers. This method is important because PAI teachers can build positive values that exist in students also improve students' ability to think.

Because of its more nature to create student understanding, in addition to the discussion, presentation, and lecture methods, PAI teachers also use the discovery-inquiry method. This method of interpretation is done by the teacher by displaying videos or films related to teaching material, after completion the video is interpreted together. Students are required to explore the positive and negative values contained therein. In this case the teacher simplifies the material. The end result of this method is that students are expected to be able to practice positive values and stay away from negative values in their daily lives based on what they have learned from the video. The method of interpretation is only used as an addition because religious material does not always focus on books but rather digs values found in society in daily life.

In classroom learning, teachers often associate the subject matter being discussed with the latest or most recent topics or cases. The goal is that students are sensitive to the circumstances. In addition, according to PAI teachers, the majority of Al-Izhar Islamic High School students are also actively following the latest information developments on religious issues. This can be seen when the teacher delivers learning material, students often ask questions about religious cases or topics that are rife in the mass media, even if they are not in accordance with the material being studied. This is permissible, because it can stimulate students to do information association activities that they get with old information that has been obtained previously.

2. Teacher become a model in the implementation of information literacy in the classroom

The role of PAI teachers to improve students' information literacy skills is also done by giving examples in using sources or references. When discussions in class take place, in the provision of opinions, the teacher often emphasizes to students to provide opinions based on valid references. That is, for habituation of this, the teacher needs to do the example in class. 
As a role model, in delivering material, the teacher uses the appropriate references. Teachers are required to convey subject matter or ideas based on reliable references and sources. In addition, this aims enrich student knowledge, and also attract students' attention. The references that usually use by teacher is al-Quran and hadith, as well as classic books, but occasionally teachers also add from other source books. In addition to allowing students to use other sources, teachers also actively assist students in finding and accessing sources of information relevant to the material being studied or by assignments that assigned to students. PAI teachers also make it a habit to read books because they will be emulated by their students.

Some of the sources used as teacher's reading material are not books that provide extreme understanding, and do not indicate intolerance values. The books read by teachers are religious reference books that have been used as references in studying Islam.

3. Provide diverse tasks that can foster students' critical thinking skills, create analysis questions as a benchmark for the development of high-level critical, logical and creative thinking

That the various forms of assignment by teachers are one of the efforts in habituating students' critical and analytical thinking. So that in learning, the involvement of students or direct participation from students can affect the success and achievement of learning objectives.

All assignments given by the teacher are in order to prioritize students to become a problem solver. And this is an indicator of information literacy, because someone who literates information is the one who can solve a problem. In order to make students to be accustomed to solving a problem in a task, teachers always ask for rational reasons for what they do. It will awaken the habit thinking of students who prioritize finding solutions. This can increase along with the frequency of students getting assignments from the teacher.

With a variety of tasks given, it allows students not only to use one source of information in learning, but various sources. This means that the teacher's role is no longer the only source of information that merely provides knowledge to their students, but rather that it is as a facilitator who provides students with a variety of information skills so that they can independently develop themselves both in terms of cognitive, psychomotor, and affective.

Teachers do resource-based learning, which is learning that focuses on what students do by using information sources such as newspapers, books, videos, computer software, and online databases to facilitate students in their own learning. With source-based learning students become independent, it is one of the standard criteria for information literacy abilities.

The assignments given by the teacher demand that the development of students' critical power. The steps taken by students in working on assignments to completion of tasks are in accordance with the information literacy cycle.

In giving assignments to students, teachers give assignments that are able to make students sensitive to the environment, so students can criticize in advance and do not immediately accept information. After class learning has ended, in an effort to provide students with a holistic and comprehensive understanding, the teacher provides several types of assignments. The shape of the assignment is adjusted to the material being studied. Among the forms of the assignment are assignments to make papers, assignment of meaning, report assignments, and kalam (speaking) assignments. 
Making paper assignments requires students to be good at finding, processing, comparing, and using the information obtained as well as possible so that it can be expressed in the form of papers that are full of meaningful knowledge.

The task of meaning aims to make students know about religious issues and information around them, then interpret positive and negative life values from these issues, then be able to learn lessons as lessons for students and students can apply them in their daily lives.

The task of the report is carried out in the form of giving a book. The task of waqf book is given to students with students given the freedom to endow their books, with the provisions given by the teacher that must be made a report on what books are represented, where students are to give a donation, the reasons for students to endow the book and the reason for choosing a place to endow, accompanied by evidence in the form of documentation. The books that have been presented are placed on the bookshelves in the classroom as a small library to be used by all students.

Teachers view the existence of the kalam task as an effort to make students literacy towards information as well as to train students to be able to speak in front of many people. The number of readings students read to get information about the theme of kalam and that best suits their needs makes students know how to search for information correctly. So that students' critical attitude towards religion has been developed. Students can already criticize and understand wrong and true information, and how to make solutions to a problem. So the teacher concluded that the majority of Islamic high school students at Al-Izhar Pondok Labu had literacy on existing information. This is not only seen from the learning activities in the classroom, it is also seen by the kalam program that must be followed by all Al-Izhar Islamic High School students. In addition there is also a social action project to the orphanage as a group assignment.

\section{B. Habituation Activities}

1. Teacher hold a collaborative learning strategies with libraries

In general, Al-Izhar Islamic High School has a trusteeship program which runs on Monday and Thursday. The program is commanded by each homeroom teacher. In the trusteeship program, students are directed by the homeroom teacher to go to the library to do activities in the library, both reading, doing assignments, and discussions with friends. The program aims to make students enjoy reading and improve students' literacy skills.

Specifically in the PAI subjects, the teacher has not collaborated directly with the library. Collaboration with the library is only done indirectly, namely in the form of suggestions to students to look for books in the library related to the task of making papers. It is only when at the end of the semester and the subject matter is finished, the teacher invites students to the library to read religious books, but only as to add insight.

For programs that are tentative in nature, the library collaborates with religious teachers. One of the activities carried out is when students do written work, or other tasks, the teacher requires students to take one or two sources from the library, so that not all sources are solely from the internet. Even the PAI teacher sometimes does not allow students to find information through several search engines on the internet, but must from the library as a bibliography.

\section{Execute school literacy programs}

Al-Izhar Islamic High School implements the School Literacy Movement program every Tuesday, Wednesday and Thursday. On that day students are given 10 minutes to 
read a book. The book used is a book outside of the textbook. This activity is intended to broaden students 'insights and to foster students' love for reading.

In the 10-minute reading activity, Al-Izhar Islamic High School students spent more than 10 minutes reading novels, not so many students reading religious books. Only a few students read religious books related to their Scientific Work assignments. But even so, according to PAI teacher information, teachers still give advice and suggestions for students to read also books related to religion but that are mild in nature, with the aim of being able to help students get more religious knowledge, given the time of religious study hours in the high school curriculum is very limited, and activities outside of school or at home not necessarily all students study religion.

The purpose of this reading activity is as follows:

1) Motivate students to want and get used to reading

2) Show that reading is a fun activity

3) Enrich vocabulary (in written language)

4) Become a means of communicating between students and teachers

5) Teach reading strategies

6) The teacher as a role model for reading (reading role models).

\section{Additional Lesson}

In supporting the success of the School Literacy Movement program launched by the government, Al-Izhar Islamic High School incorporated local literacy content into the school curriculum which later on the subjects were called Scientific Work subjects. The scientific work is aimed at cultivating literacy so that students can become lifelong learners.

Schools provide freedom about the themes students want to study. Of the many students who took up the theme of social life, politics, health, there were also students who took up religious themes, including writing about the problem of corruption, comparison between Nahdlatul Ulama and Muhammadiyah, and deviant behavior.

Students already have good writing skills, this is known from the writing techniques that students use, students already understand the procedures for making scientific work from the background of the problem to making a bibliography. Students have a good knowledge of religious issues that are necessary and important to be investigated. Some themes or problems that students make research are interesting problems. So for the level of high school students, the authors assume they already have the ability at an excellent level regarding their curiosity on the issue of religion.

Students use several sources of accurate information in making work. References that students use come from valid sources of information. Students include every source in each citation. In addition to students using sources from books, students also use references from other people's research (theses) and sources from the internet.

Students have been able to analyze well the information related to the problems they take. With the information students get from several sources, as well as information from interviews, at least they can sort out information, and students can have their own opinions and solutions regarding the religious problems they study.

\section{Discussion}

PAI teachers have played an active role in enhancing students' information literacy skills. This is known by the use of several learning methods that all emphasize students to be able to develop their critical thinking skills. In learning, teachers often associate learning 
material with recent topics, teachers provide examples in the use of references, give assignments and make analytical questions, carry out school literacy programs, support the existence of scientific work subjects, and conduct collaborative activities between PAI teachers and Al-Izhar Islamic High School library. So with these efforts Al-Izhar Islamic High School students became very critical in responding to information. Many students ask about religious issues in class, although this is sometimes outside the subject matter of showing that Al-Izhar Islamic High School students care about the information circulating, they have high curiosity, even though most of them do not then just accept the information.

Compatibility of information literacy implementation with AASL indicators:

To find out whether there is an increase in students of the implementation of information literacy, it is necessary to know the suitability of the implementation of information literacy with American Association of School Librarians.

First, that the learning method used by PAI teachers is able to make students compile questions based on their information needs, this is in accordance with AASL School Information Literacy Standard L1-1 (Indicator 3). Students are able to recognize the need for AASL School Information Literacy Standard L1-1 (Indicator 1). With the presentation method, students are able to integrate new information into one's knowledge, in accordance with AASL School Information Literacy Standard L1-3 (Indicator 2). Students have been able to choose information that is appropriate for a problem or question, this is in accordance with AASL School Information Literacy Standard L1-2 (Indicator 4).

The discussion method allows students to be able to share knowledge and information with others. Students are able to work together with others to identify information problems and find solutions. This is in accordance with the AASL School Information Literacy standard L33 (Indicator 3). Students can distinguish positive and negative information that they get from the media, indicating that they have been able to achieve AASL School Information Literacy Standard L1-2 (Indicators 2 and 3), ie students have been able to distinguish between facts, views, and opinions, and students has been able to identify inaccurate and misleading information.

Second, in other side, teachers have tried to make students literacy towards information starting from the examples given by the teacher in the teaching and learning process in the classroom. The teacher exemplifies and emphasizes to students to always use accurate and trusted references in information retrieval activities, both for assignments and for all their needs in daily life. With this example, the teacher makes students able to develop and use good strategies for finding information, in accordance with AASL School Information Literacy Standard L1-1 (Indicator 5), and that students are aware of differences in opinion of the school's priests on an issue, showing that students have been able to examine the quality of the process and product of personal information search, as is the AASL School Information Literacy Standard L2-3 (Indicator 1).

Third, teacher provide diverse task that can make student have problem solving skills. The ability of students who can solve problem in accordance with Standard L1-3 School Information Literacy, namely students are able to apply information into critical thinking and problem solving (Indicator 3).

Fourth, the collaboration between the teacher and the library, it is hoped that it can help students to meet the AASL School's Literacy Information Standard L3-1, where students value the principle of access to adequate information (Indicator 2).

Fifth, scientific work subjects can develop student mastery to be able to recognize that accurate and comprehensive information is the basis of good decision making and students are able to identify a variety of potential sources of information (AASL School Information 
Literacy Standard L1-2, Indicators 2 and 4). However, according to the author, so that AlIzhar Islamic High School students become more literate towards religious information, in making scientific works the teacher needs to direct more students so that they can make more works that raise religious themes.

\section{Conclusion}

The information literacy ability of Al-Izhar Islamic High School students has demonstrated good ability with the achievement of all indicators of AASL school information literacy. Students have been able to search, analyze, use, and communicate information well in the making of assignments and other works (information category). Students can learn independently (independent learning), with guidance from the teacher and the school library. In daily religious attitudes, students have been able to show a sense of social responsibility towards the surrounding environment. All of these capabilities are in accordance with AASL School Information Literacy Standards, namely Information Literacy Mastery Standards, Independent Learning Standards, and Social Responsibility Standards, with each standard consisting of several indicators of achievement.

\section{Ackowledgement}

The author wish to thank Faculty of Social Sciences State University of Jakarta.

\section{References}

[1] Sailah, Illah. 2018. Pembelajaran 4.0 Merespon Era Revolusi Industri.

[2] Thompson, Helen M., dan Susan A. Henley. 2000. Fostering Information Literacy. Colorado: Libraries Unlimited, Inc.

[3] VOA Indonesia. 2019. https://www.voaindonesia.com/a/bin-usia-17-24-tahun-rentanterpapar-radikalisme/5038396.html

[4] Wahid Foundation. 2017. http://wahidfoundation.org/index.php/news/detail/WahidFoundation-Goes-to-School-of-Tasikmalaya

[5] American Association of School Librarian. 1998. Information Literacy Standards For Student Learning. America: the American Library Association and the Association for Educational Communications and Technology.

[6] Cambridge Assessment. 2013. What is literacy? An investigation into definitions of English as a subject and the relationship between English, literacy and 'being literate'. A Research Report Commissioned by Cambridge Assessment.

[7] Al-Izhar. 2014. http://www.al-izhar-jkt.sch.id/index.php/akademi/sekolah-menengahatas/

[8] Creswell, John W. 2014. Research Design: Qualitative, Quantitative, and Mixed Methods Approaches.

[9] Eisenberg, Michael B., Lowe, Carrie A., Spitzer, Kathleen L. 1998. Information Literacy: Essential Skills for The Information Age. New York: ERIC Clering House on Information \& Technology Syracuse University.

[10] Emzir. 2011. Metodologi Penelitian Kualitatif: Analisis Data. Jakarta: PT. RajaGrafindo Persada.

[11] Riedling, Ann Marlow. 2004. Information Literacy: What Does It Look Like in the School Library Media Center. Connecticut: Libraries Unlimited. 
